\title{
PELAKSANANAN REHABILITASI TERHADAP PECANDU NARKOBA SECARA SUKARELA DAN MELALUI PROSES PENEGAKAAN HUKUM. (STUDI KASUS DI BBNP JATENG)
}

\author{
Petrus Soerjowinoto, Tri Mulyo Wibowo, Simon Hermawan Baskoro*
}

\begin{abstract}
Indonesia is in a state of drug emergency, the prevalence of drug abuse is increasing, the growth of drug abuse users is already alarming and alarming. Ignorance of the dangers and risks of drug use will add to the victims of drug abuse. Efforts to solve drug problems are carried out in cross-sectoral aspects of preventive and repressive aspects. Based on the mandate of the regulation of drug addicts must undergo rehabilitation. Rehabilitation is an alternative sanction in the form of actions stipulated in a joint regulation. There are two ways that rehabilitation of drug abuse can be done voluntarily and through law enforcement processes and there is no involvement in the distribution of drugs. This paper will discuss about (1) the implementation of rehabilitation for drug addicts voluntarily (2) the implementation of rehabilitation for drug addicts through the process of law enforcement.
\end{abstract}

Keywords : the regulation, drug addicts, law enforcement.

\section{PENDAHULUAN}

Indonesia dinyatakan dalam keadaan darurat nakoba. ${ }^{1}$ Puluhan orang pecandu dan korban penyalahgunaan narkoba meninggal setiap harinya. ${ }^{2}$ Tertkait dengan pernyataan tersebut merupakan ancaman yang lebih besar dibanding dengan ancaman yang lain misalnya: terorisme, radikalisme, dan kejahatan yang lain. Ancaman pecandu

* Petrus Soerjowinoto, Tri Mulyo Wibowo, Simon Hermawan Baskoro adalah Pengajar di Fakultas Hukum Universitas Soegijapranata Semarang dapat dihubungi melalui email : petrus @unika.ac.id

1 Pidato Presiden Joko widodo pada hari Selasa tanggal 20 Januari 2015 di Pontianak kalimantan Barat, mengatakan bahwa Indonesia berada dalam status darurat narkoba pada saat ini. Oleh karena itu, tidak ada maaf bagi pelaku narkoba di negeri ini.

2 Menurut Komjen Budi Waseso Kepala Badannarkoba Nasional mengatakan bahwa "Setiap hari ada 30-40 orang yang mati karena narkoba," Lihat Kompas. com, Senin 11 januari 2016. dan korban penyalahgunaan narkoba membawa dampak gagalnya pembinaan generasi muda, perubahan perilaku di bidang: Sosial, Kesehatan, Ekonomi dan akhirnya mengarah pada meningkatnya kejahatan. Pemberantasan kejahatan narkoba melalui penegakan hukum berujung pada penjara menjadi over capacity. Prevalensi penyalahgunaan narkoba meningkat. Secara khusus kondisi penyalah gunaan narkoba dirasa sudah mengkawatirkan dan memprihatinkan. Pertumbuhan penggunaan penyalahgunaan Narkoba terjadi perkembangan sebagai berikut : (1) Tahun 2004 terjadi pertumbuhan 3,2 juta jiwa, (2) Tahun 2008 terjadi pertumbuhan 3,6 juta jiwa, ${ }^{3}$ (4) Pada tahun 2015 meningkat hingga 5,9 juta. ${ }^{4}$ Berdasarkan uraian tersebut di atas dapat diketahui bahwa sejalan dengan prevalensi meningkatnya penyalahguna narkoba, maka akan diiumbangi dengan permintaan narkoba yang meningkat.

3 Pernyataan Ka. Bag Humas BNN Sumirat Dwiyanto, Kompas.com Senin 19 Oktober 2009 4 Ibid, Kompas.com Senin, 11 Januari 2016 
Bisnis narkoba juga akan meningkat sesuai dengan hukum permintaan dan penawaran (supply and demand), Bisnis ini merupakan hal yang sangat menguntungkan dan menjanjikan bagi pengedar. Akibat dari permintaan narkoba meningkat, maka tumbuh home industri narkoba baru dengan segala macam variannya untuk memenuhi permintaan serta melakukan perekrutan pengguna baru narkoba maupun pengedar.Tumbuh mafia narkoba baru, disebabkan oleh keinginan mendapat kan uang dengan mudah dan keuntungan yang banyak dalam waktu yang singkat.

Berdasarkan pertimbangan Undang undang No 35 tahun 2009 butir 4 dinyatakan: ... "tindak pidana narkoba telah bersifat transnasional yang dilakukan dengan menggunakan modus operandi yang tinggi, teknologi canggih, didukung oleh jaringan organisasi yang luas, dan sudah banyak menimbulkan korban, terutama di kalangan generasi muda bangsa yang sangat membahayakan kehidupan masyarakat...". ${ }^{5}$

Motivasi penggunaNarkoba adalah mencari kenikmatan, bahaya dan risiko penggunaan narkoba akan menambah korban penyalahgunaan narkoba. Hal tersebut merupakan masalah serius yang harus ditanggulangi.

Upaya dalam menyelesaikan permasalahan narkoba sudah dilakukan secara lintas sektoral baik dari aspek preventif maupun represif.

1. Secara preventif, dilakukan oleh aparat yang berkepentingan khususnya dari BNN, POLRI. PPNS dan melalui partisipasi aktif masyarakat yaitu dengan munculnya lembaga-lembaga yang didirikan oleh masyarakat.

2. Secara Represif, dilakukan melalui proses peneggakan hukum mulai dari penangkapan, penahanan, penuntutan, pemeriksaan di muka sidang

5 Konsideran Undang-undang Nomor 5 Tahun 2009 butir 4 tentang Narkoba, Lembaran Negara Republik Indonesia Nomor 143. pengadilan dan sampai dengan proses hukum di lembaga pemasyarakatan. Namun demikaian hasilnya belum memberikan sesuatu yang meng gembirakan sebaliknya prevalensi penyalahguna narkoba tidak berkurang bahkan bertambah.

Amanat peraturan perundangundangan tentang pecandu narkoba wajib menjalani rehabilitasi. Peraturan tersebut diakomodir oleh 7 (tujuh) lembaga negara yang mengutamakan pelaksanaan rehabilitasi bagi pecandu narkoba. ditetapkan dalam Peraturan Bersama tentang Penanganan Pecandu Narkoba dan Korban Penyalahgunaan Narkoba yaitu:

a. Peraturan Nomor: 01/PB/MA/III/ 2014, Mahkamah Agung Republik Indonesia

b. Peraturan Nomor: 03 Tahun 2014, Menteri Hukum dan Hak Asasi manusia

c. Peraturan Nomor: 11 Tahun 2014, Menteri Kesehatan

d. Peraturan Peraturan Nomor: 03 Tahun 2014, Menteri Sosial Republik Indonesia

e. Peraturan Nomor: PER-005/A/JA/03/ 2014, Jaksa Agung Republik Indonesia

f. Peraturan Nomor: 1 Tahun 2014, Kepala Kepolisian Negera Republik Indonesia

g. Peraturan Nomor: PERBER/01/III/ 2014/BNN Kepala Badan Narkoba Indonesia

Berdasarkan uraian tersebut di atas pecandu narkoba tidak lagi bermuara pada sanksi pidana penjara, melainkan bermuara pada tindakan yang berupa rehabilitasi. oleh karena sanksi bagi pecandu ditetapkan berupa rehabilitasi dalam peraturan bersama Pasal 54 Undang-undang No. 35 Tahun 2009 tentang narkoba mengamanat kan pengguna narkoba wajib menjalani rehabilitasi medis dan rehabilitasi sosial. Korban penyalahgunaan narkoba wajib menjalankan pemulihan terhadap dirinya 
baik dari segi medis terhadap kesehatannya dan pemulihan nama baik bagi para pengguna untuk kembali ke masyarakat.

Ada 2 (dua) cara yang dapat dilakukan oleh BNN dalam melakukan rehabilitasi bagi para korban penyalahguna an narkoba, yaitu dengan cara:

1. Sukarela/volunteer, pengguna secara sadar datang ke BNN dan mempunyai keinginan untuk segera pulih dari bahaya narkoba yang di konsumsinya, dan kemudian nantinya pengguna akan diperiksa oleh Tim Assesment Terpadu (TAT) terkait dengan berapa besarnya penggunaan yang di konsumsi yang berpedoman Surat Edaran Mahkamah Agung Nomor 04 Tahun 2010.

2. Proses penegakan hukum, pengguna dalam hal tertangkap tangan ia akan terlebih dahulu menjalani proses hukum dan kepadanya tidak terlibat dalam peredaran gelap narkoba yang kemudian diperiksa oleh Tim Assesment Terpadu (TAT).

Terkait dengan pelaksanaan rehabilitasi pengguna yang tertangkap tangan harus didahului proses pengadilan. Pencandu yang tertangkap tangan akan menjalani proses peradilan terlebih dahulu. Terdakwa diperiksa dan diputus berdasar kan hukum acara pidana yang belaku dan berapa tahun sanksi pidana yang dijatuhkan oleh hakim serta proses rehabilitas yang akan dijalani. Tersangka harus ada asesment terpadu (TAT) dari Jaksa BNN, polisi dan dokter, hasilnya dimasukkan ke dalam berkas perkara kemudian diserahkan ke pengadilan sebagai dara pertimbangan hakim untuk menjatuhkan putusan.

Bidang rehabilitasi BNN Provinsi Jawa Tengah berupaya untuk memulihkan kondisi kesehatan pengguna narkoba seperti semula untuk pengguna narkoba. Rehabilitasi bagi pengguna narkoba wajib menjalani rehabilitasi medis dan sosial. Rehabilitasi medis dilakukan di rumah sakit yang ditunjuk oleh kementrian kesehatan, dengan biaya APBN. Rehabilitasi sosial diselenggarakan di Balai Rehabilitasi Sosial Mandiri Provinsi Jawa Tengah, dibawah naungan Dinas Sosial Provinsi Jawa Tengah. Selama menjalani pemulihan di panti rehabilitasi, kemudian menajalani pasca-rehab melalui program pendamping an. Tujuannya adalah (1) untuk memantau apakah pengguna narkoba sudah pulih kembali seluruhnya atau belum, dan (2) pengguna narkoba setelah kembali ke masyarakat tetap di pantau oleh Tim Assesment Terpadu (TAT).

Undang-undang Nomor 35 tahun 2009 tentang narkoba menganut dua pilihan (double tract sytem) hukuman bagi penyalahguna narkoba yang berupa sanksi penjara dan sanksi tindakan berupa rehabilitasi, berdasarkan Pasal 103 Undang-undang No 35 tahun 2009 tentang narkoba. Hukumnan pidana yang berupa rehabilitasi medis dan sosial untuk menjalani pengobatan agar pecandu dapat sembuh dan tidak mengulangi perbuatanya kembali. ${ }^{6}$ Penekanan efek jera saja terhadap pecandu narkoba dengan memberikan sanksi pidana penjara tidak akan menyelesaikan permasalah narkotika, karena ini sama artinya hanya memindahkan pecandu narkoba kedalam tembok dan jeruji penjara tanpa adanya pengobatan, pada dasarnya pecandu narkoba memiliki sifat ketergantungan atau adiksi yang tinggi terhadap narkoba, sehingga perlu dilakukan bantuan pihak lain untuk dilakukan pengobatan agar dapat disembuhkan.

Terkait dengan rehabilitasi ter tangkap tangan, hal yang harus perlu diingat seorang pecandu narkoba tidak akan sembuh dengan sendirinya terhadap ketergantungannya, sehingga hal ini akan membuat pelaku tetap akan mengulangi perbuatannya kembali yaitu menggunakan narkoba dan nantinya mungkin ditangkap kembali menjadi residivis.pecandu narkoba juga dapat dikatakan sebagai korban

6 Salah satu tujuan dibentuknya Undang-undang narkoba melalui Pasal 54 yang menyatakan bahwa pecandu dan korban penyalahgunaan narkoba wajib menjalani rehabilitasi medis dan rehabilitasi sosial. 
berdasarkan, "teori tipologi korban yang di indentifikasi menurut keadaan dan status yaitu self victimizing victims merupakan orang yang menjadi korban karena kejahatannya sendiri". Rehabilitasi merupakan paradigma baru dalam menangani pecandu narkotika. Aparat penegak hukum harus berorientasi kepada sanksi berupa rehabilitasi demi me nyelamatkan generasi bangsa dari bahaya narkoba, guna memfungsikan peran hakim dalam menjatuhkan keputusan rehabilitasi perlu dukungan. Undang-undang narkoba memberlakukan kebijakan yang humanis khususnya terhadap pecandu dan korban penyalahgunaan narkoba, sehingga diperlukan kebijakan-kebijakan untuk menjalankan amanat Pasal 54 Undangundang Narkoba. Rehabilitasi dilakukan untuk mewujudkan dan melaksanakan amanah dari Undang-undang Narkotika. Berdasarkan uraian tersebut di atas, tulisan ini akan memaparkan dua masalah pokok yaitu:

1. Bagaimana Pelaksanaan Rehabilitasi Bagi Pecandu Narkoba Secara sukarela?

2. Bagaimana Pelaksanaan Rehabilitasi Bagipecandu Narkoba Melalui Proses Penegakan Hukum?

\section{PELAKSANAAN REHABILITASI BAGI PECANDU NARKOBA SECARASUKAREALA?}

Pelaksanaan rehabilitasi bagi pecandu narkoba secara sukarela wajib dilakukan rehabilitasi medis terlebih dahulu, baru kemudian rehabilitasi sosial. Terhadap proses ini, pecandu harus menjalani rehabilitasi sampai sembuh. Prosesnya dilakukan asesmen, pemeriksa an urin atau rambut, wawancara dilakukan untuk pemeriksaan fisik untuk mengetahui tingkat kesehatannya dan pemberian terapi simptomatik serta rencana terapi.

7 Rena Yulian, 2009, victimology, Yogyakarta : Graha Ilmu, hal 54.
Proses asesmen tersebut juga untuk mengetahui yang bersangkutan terlibat dalam peredaran narkoba atau tidak, serta mempunyai riwayat berurusan dengan hukum atau tidak. Jika hasilnya menunjukan tidak ada riwayat terlibat dalam peredaran narkoba dan berurusan dengan hukum serta menunjuk hasil rujukan yang bersangkutan harus rawat jalan atau rawat inap, maka dimintakan hasil asesmen dengan jangka waktu 6 hari kemudian diambil kesimpulan. ${ }^{8}$

Terkait dengan rehabilitasi bagi pecandu narkoba secara sukarela, maka BNN Propinsi berfokus pada rawat jalan. Namun demikian, jika dalam asesmen menunjukkan adanya gejala lain yang timbul seperti gangguan mental/ psikis, maka korban harus dirujuk dan dilakukan rawat inap.

Tim dokter mengasesmen pasien yang berisi hasil pemeriksaan vital yaitu: dilakukan pemeriksaan urine untuk mendeteksi narkoba di dalam tubuh pasien. Berdasarkan hasil temuan dokter, direncanakan terapi bagi si pasien dan juga pemberian informasi medis kepada pasien berupa pemahaman pemulihan akan penyakit pasien, setelah itu dokter merujuk kepada Institusi Penerima Wajib Lapor (IPWL) untuk dilakukan serangkain perawatan yang berupa rawat jalan atau rawat inap tergantung dari kondisi si pasien tersebut dengan metode rehabilitasi seperti dibawah ini:

\section{Metode Rehabilitasi Badannarkoba Nasional}

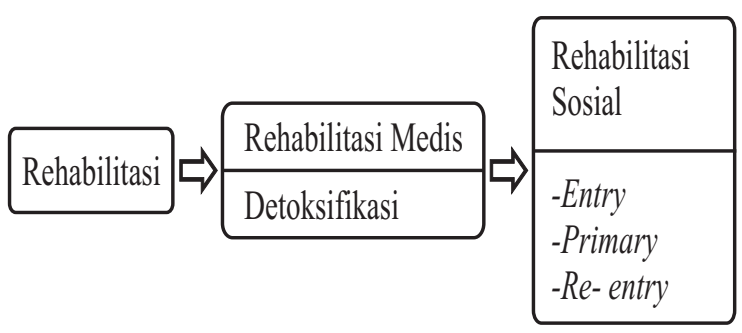

8 Hasil Wawancara dengan Igor Budi Mardiyono, Kepala Bidang Rehabilitasi BNNP Jawa Tengah, pada tanggal19 Okotober 2016. 
Metode rehabilitasi di atas dapat dijelaskan bahwa pengguna terlebih dahulu menjalani (1) rehabilitasi medis dengan program detoksifikasi di BNN Propinsi, kemudian dilanjutkan (2) rehabilitasi sosial dengan 3 (tiga) tahapan yaitu Entry, Primary, dan Re-entry yang kemudian dapat dijelaskan seperti di bawah ini:

\section{a. Rehabilitasi Medis}

Pada Tahapan ini korban akan menjalani proses detoksifikasi selama 2 (dua) minggu dengan mengeluarkan racunracun dalam tubuh korban dan bertujuan untuk menatalaksanakan kondisi akut dari intoksifikasi maupun putus zat diikuti dengan pembersihan zat dari tubuh pecandu. Melalui program ini detoksifikasi akan dapat meminimalisasi dampak terhadap fisik yang disebabkan dari penggunaan narkoba. Proses rehabilitasi berfokus pada rawat jalan terhadap detoksifikasi yang selama 3-6 bulan, dan tidak menutup kemungkinan adanya relaps terhadap para korban yang kemungkinan menggunakan narkoba kembali. Namun demikian, jika si pecandu dikatakan parah, maka akan di rujuk di BNN Pusat. Institusi Penerima Wajib Lapor (IPWL) yang melakukan rawat jalan memberi kan hak kepada pasien biaya gratis di Rumah Sakit atau Puskesmas yang di tunjuk oleh Kementrian Kesehatan. Namun ada juga IPWL yang di kelola oleh swasta dengan biaya sendiri yang berbentuk yayasan seperti Rumah Damai, dan Ponpres Al-Tauhid.

Peraturan Menteri Kesehatan Nomor 50 Tahun 2015 Tentang Tentang Petunjuk Teknis Pelaksanaan Wajib Lapor dan Rehabilitasi Medis Bagi Pecandu, Penyalahguna, dan Korban Penyalahguna narkoba, melampirkan prosedur layanan

9 Hasil Wawancara dengan Igor Budi Mardiyono, Jabatan : Kepala Bidang Rehabilitasi BNNP Jawa Tengah, pada tanggal19 Okotober 2016 Pukul 10.15 WIB. bagi pecandu, penyalahguna, dan korban penyalahguna narkoba yang melaporkan diri secara sukarela, yang meliputi:

1). Asesmen mengunakan formulir asesmen wajib lapor dan rehabilitasi medis.

2). Tes Urine untuk mendeteksi ada atau tidaknya narkoba di dalam tubuh.

3). Pemberian konseling dasar adiksi NAPZA, yang ditujukan untuk mengkaji pemahaman pasien atas penyakitnya serta pemahamannya akan pemulihan. Pemberian konseling dasar juga dimaksudkan untuk meningkatkan motivasi pasien dalam melakukan perubahan perilaku ke arah yang lebih positif.

4). Pecandu narkoba yang memiliki riwayat penggunaan NAPZA dengan cara suntik, diberikan konseling pra-tes HIV dan ditawarkan untuk melakukan pemeriksaan HIV mengikuti prosedur yang berlaku.

5). Pemeriksaan penunjang lain (bila perlu).

6). Penyusunan rencana terapi meliputi rencana rehabilitasi medis dan rehabilitasi sosial, dan intervensi psikososial.

7). Rehabilitasi medis sesuai rencana terapi yang dapat berupa rawat jalan dan rawat inap.

Rumah Sakit Dr. Gondohutomo Semarang merupakan salah satu rumah sakit yang di tunjuk oleh Kementrian Kesehatan sebagai IPWL untuk menangani pasien yang menjalani rehabilitasi medis. Rehabilitasi medis, merujuk pada Peraturan Menteri Kesehatan Nomor 50 Tahun $2015^{10}$ dengan metode rehabilitasi primer (wajib) yang dilakukan selama 3 bulan, dan kemudian melakukan evaluasi lanjut selama 3 bulan. Terapi yang digunakan dalam melakukan rehabilitasi medis adalah terapi simtomatis yaitu terapi untuk

10 Hasil wawancara dengan dr. Siti Badriyah. Dokter RSJD Gondohutomo Semarang, pada tanggal 09 Desember 2016, pukul 11.00 WIB. 
mengetahui gejala yang, biasanya pasien dalam keadaan sakit, seperti diare, pusing dan cemas, walaupun terapi simtomatis tersebut hampir sama dengan detoksifikasi.

Jenis rehabilitasi medis dapat berupa rehabilitasi medis rawat jalan dan rehabilitasi rawat inap. Rehabilitasi rawat jalan dapat berupa terapi simtomatis. ${ }^{11}$

Pasien rawat jalan kepadanya diberikan obat-obatan untuk menunjang pemulihan bagi dirinya seperti obat simtomatis dan obat anti depresan serta obat anti psiatik, obat simtomatis untuk menyembuhkan gejala yang muncul pada pasien, sedangkan obat depresan digunakan untuk menyembuhkan pasien yang mengalami depresi atau gangguan perilaku akibat penggunaan jenis narkoba tertentu yang menyebabkan gangguan perilaku kepada pasien.

Rumah Sakit dr. Gondohutomo Semarang juga melakukan rehabilitasi sosial, namun pihak rumah sakit bekerjasama dengan Balai Rehabilitasi Sosial Mandiri Semarang terkait dengan penyelenggaraan rehabilitasi social tersebut. ${ }^{12}$ Yayasan rumah damai juga melakukan rehabilitasi medis dan sosial, namun sedikit berbeda dengan porgram yang dilakukan oleh BNNP, yayasan rumah damai sendiri mempunyai cara sendiri dalam mengelolanya seperti terapi yang diberikan kepada para korban adalah dengan terapi paksa badan, dimana para korban tersebut harus menahan dirinya dari segala bentuk kesakitan yang dialaminya.

\section{b. Rehabilitasi Sosial}

Ada 3 (tiga) tahapan dalam rehabilitasi soaial yaitu: Entry, Primary, dan Re-entry seperti di bawah ini:

\section{1). "Entry" atau Orientasif Induction}

Tahapan ini tujuan utamanya adalah melakukan pengenalan untuk beradaptasi dengan pengenalan program TC (Therapy Community) dan penyesuaian diri terhadap berbagai aturan di tempat rehabilitasi yang dilakukan selama 2 minggu.

Kegiatan komunitas pada tahap ini orientasi berfokus kepada penyesuaian diri melalui beberapa strategi spesifik yaitu isolasi relatif, intervensi krisis, orientasi fokus dan konseling

\section{2). "Fase Primay"}

Pada tahapan ini residen mulai bersosialisasi dan tergabung dalam komunitas terstruktur yang memiliki hierarki, jadwal harian, terapi kelompok, grup seminar dan departemen kerja sebagai media pendukung perubahan diri yang dilakukan selama 4 bulan. Fase primary terdiri dari 3 (tiga) tahap, semakin tinggi tahap rehabilitasi, maka hak dan kewajiban akan semakin besar dalam bersosialisasi dengan komunitas dalam kelompok yaitu: (1) tahap younger member, (2) tahap middle member dan (3) tahap older member.

\section{3). "Fase Re-Entry"}

Fase ini adalah tahapan ahkir dari program Therapy Community, dimana pasien berada dalam tahap adaptasi dan besosialisasi dengan masyarakat luas diluar komunitas pasien yang sebelumnya telah dipersiapkan melalui program pola hidup sehat dan produktif berbasis konservasi alam. Para pecandu setelah menjalani proses rehabilitasi medis dan rehabilitasi sosial, selanjutnya akan menjalani rehabilitasi tahapan selanjutnya yaitu pasca-rehab, dimana pasca-rehab ini adalah orang-orang yang dianggap telah selesai menjalani program rehabilitasi medis dan sosial. Pasca-rehab merupakan suatu rangkaian yang utuh dan tak terpisahkan dari proses rehabilitasi yang saling berkesinambungan. Institusi Penerimaan Wajib Lapor (IPWL) milik swasta (Yayasan 
Rumah Damai) juga mempunyai layanan rehabilitasi sosial sendiri, menerapkan hal yang mirip dengan yang dilakukan seperti pada IPWL milik pemerintah. Pada rumah damai kegiatan sosial yang biasanya dilakukan sekitar 2 (bulan) seperti: (1) pengenalan ke masyarakat sekitar, (2) menjalankan program usaha dengan modal yang di berikan, (3) pelatihan membuat suatu memanajemen keuangan kepada peserta yang ingin melakukan kegiatan usaha, (4) magang atau pelatihan kerja di cafe yang didampingi oleh para konselornya dan kemudian diajarkan bagaimana memanajemen keuangannya, (5) bersosialisasi dengan pelanggan membuat mereka akan semakin pulih dan ahkirnya dapat diterima oleh masyarakat.

\section{c. Layanan Siswa Rumah Damai Semarang}

Proses rehabilitasi medis dan rehabilitasi sosial layanan siswa masuk ke rumah Damai prosedurnya dapat dilhat pada diagram di bawah ini;

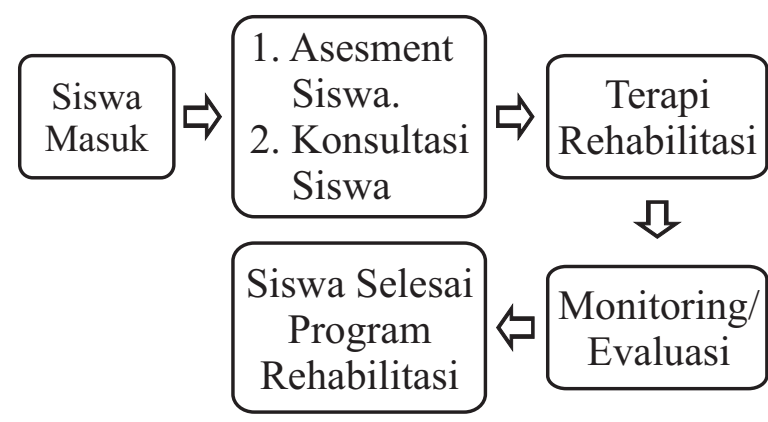

Prosedur rehabilitasi di rumah damai Semarang dapat di jelaskan sebaabagi berikut; (1) Pada saat siswa masuk dilakukan pendafaran, (2) siswa di buatkan rekam medik, berupa asesment dan konsultasi siswa yang berupa penapisan dan penentuan program rehabilitasi terhadap siswa, (3) siswa menjalankan terapi rehabilitasi yang meliputi terapi rohani, terapi fisik, terapi sosial, pembentukan karakter, dan kesehatan. (4) Monitoring dan evaluasi program siswa jika sudah dianggap sembuh dari penggunaan narkoba yang kemudian dipantau setiap kegiatannya dan dievaluasi setiap kegiatan yang berupa kesanggupan fisik, kesanggupan mental dan kesanggup an sosial. (5) jika sudah pulih maka siswa dinyatakan telah berhasil dan selesai menjalani program rehabilitasi di rumah damai yang kemudian bisa pulang ke keluargannya.

\section{Pasca-Rehabilitasi}

\section{a. Tahap Orientasi Program}

Tahap ini ditujukan untuk memberikan pembekalan dan pengenalan program sesuai jenis program yang ada serta menjadikan mantan pecandu terbiasa dengan kondisi lingkungan. Kegiatan pada tahap ini diarahkan kepada penyiapan mental percaya diri, pemantapan disiplin diri yang sudah dibentuk dalam tempat rehabilitasi dan pengenalan kondisi lingkungan termasuk tata tertib yang berlaku yang selama 2 minggu menjalani program.

\section{b. Tahap Pelatihan dan Praktik}

Tahap ini ditujukan untuk memberikan berbagai keterampilan mantan pecandu dan dilanjutkan dengan praktik sampai memperoleh hasil yang diharapkan. Kegiatan pada tahap ini adalah pemberian ketrampilan sesuai bakat dan minat, praktik sesuai dengan ketrampilan yang telah di berikan dan intregrasi sosial dengan masyarakat sekitar yang selama 4 minggu mengikuti atau menajalankan program.

\section{c. Tahap Evaluasi Hasil dan Penyiapan Praktik Kerja Lapangan}

Tahap ini ditujukan untuk melakukan evaluasi secara menyeluruh dan penyiapan mantan pecandu yang akan memasuki kehidupan yang sesungguhnya 
dengan berbekal ketrampilan yang telah dimiliki selama mengikuti program pascarehabilitasi yang selama 2 minggu. Hasil evaluasi akan digunakan sebagai bahan masukan untuk program berikutnya yaitu rumah dampingan dan rumah mandiri. Layanan pasca-rehab di BNNP Jawa Tengah dan di BNN Pusat berfokus pada pelatihan pengembangan kewirausaha an, Layanan pasca rehab BNN Pusat terdapat 2 (dua) macam yaitu: (1) berbasis konservasi hutan dan (2) konservasi berbasis laut sebagai berikut;

a) Konservasi berbasis hutan dilakukan selama 2 (dua) bulan, yang kemudian di bagi menjadi 3 (tiga) fase yaitu masa orientasi, masa pelatihan dan Praktik, masa evaluasi pengahkiran. Konservasi berbasis hutan ini dalam masa orientasi memerlukan waktu 2 minggu yaitu berupa pengenalan tentang hutan serta fungsi hutan, yang kemudian dilakukan pelatihan yang memerlukan waktu 4 minggu dengan terjun ke hutan yang akan dituju serta melakukan penanam an pohon dihutan secara bersamasama, yang kemudian masa evaluasi program yaitu dengan memberikan evaluasi hasil pelatihan yang dikerjakan selama masa pelatihan/ Praktik dengan diahkiri dengan masa pengahkiran.

b) Konservasi berbasis laut dilakukan selama 2 (dua) bulan yang juga membagi menjadi 3 (tiga) fase yaitu: (1) masa orientasi, (2) masa pelatihan/ praktik dan (3) masa evaluasi/ pengahkiran. Konservasi berbasis laut ini memerlukan waktu 2 minggu untuk masa orientasi atau masa pengenalan akan laut serta fungsi laut, dilanjutkan masa pelatihan/praktik yang memerlukan waktu 4 minggu dengan penanaman pohon bakau, pembersihan bibir pantai, yang kemudian dilakukan masa evaluasi selama 2 (dua) minggu untuk mengevaluasi hasil kerja dan Praktik di laut yang setelah itu diahkiri masa pengahkiran.

\section{Penyiapan Kembali Ke Keluarga}

\section{a. Rumah Damping}

Mantan pecandu yang telah menjalani program pasca-rehab bersama dengan mantan pecandu yang telah mengikuti layanan pasca-rehab dengan jumlah paling banyak hanya 10 orang dan di dampingi oleh konselor, pekerja social, dan tenaga medis yang bertugas memantau serta membimbing mereka bilamana timbul permasalahan baik berkaitan dengan pekerjaan atau yang berhubungan dengan keluarganya. Program yang biasanya dilakukan adalah " family group". Program ini adalah membentuk suatu komuntias antar keluarga mantan pecandu dengan membuat suatu diskusi bersama. Program "Home Visit" program ini bersama konselor berkunjung ke tempat yang bersangkutan untuk bertemu dengan keluarga yang dimiliki nya serta keluarga bisa melihat perkembangan mantan pecandu yang telah menjalani berbagai macam program yang mereka tempuh selama 2 (dua) bulan. ${ }^{13}$

\section{b. Rumah Mandiri}

Pada dasarnya Rumah Mandiri hampir sama dengan dengan apa yang telah dilakukan di rumah damping. Bedanya, di rumah mandiri konselor pekerja sosial atau tenaga medis sebagai pendamping tidak tinggal bersama. Namun para pendamping secara periodik 2 (dua) kali seminggu untuk melakukan pemantauan dan evaluasi atau pemeriksaan rutin. Mereka dapat dihubungi setiap saat apabila ada mantan residen yang membutuhkan. Terhadap keseluruhan proses rehabilitasi medis dan rehabilitasi sosial dan tidak menutup kemungkinan

13 Hasil Wawancara dengan Igor Budi Mardiyono, Kepala Bidang Rehabilitasi BNNP Jawa Tengah, pada tanggal 19 Okotober 2016 Pukul 10.15 WIB. 
pasca-rehab merupakan suatu rangkaian utuh dan tidak terpisahkan. Keseluruhkan proses tersebut juga tidak bisa menjamin klien akan pulih tetapi memfasilitasi agar klien tersebut pulih, dan tidak menutup kemungkinan juga klien tersebut relaps kembali jika klien tersebut tidak ada rasa keinginan untuk pulih dari bahaya narkoba dalam dirinya dan segera menghilangkan racun dalam tubuh. Kesadaran akan hal tersebut adalah yang utama dalam setiap rangkaian rehabilitasi tersebut. Namun demikian, Undang-undang Nomor 35 Tahun 2009 Tentang narkoba tidak mengatur ketentuan yang mewajibkan melakukan pasca-rehab. Dengan demikian, sesuai dengan amanat undang-undang tersebut dan pasca-rehab tergantung inisiatif orang tersebut apabila dirasa butuh melakukan pasca-rehab atau tidak.

\section{PELAKSANAAN REHABILITASI BAGI PECANDU NARKOBA MELALUI PROSES PENEGAKAN HUKUM.}

BNN memberikan perlakuan dan penanganan khusus terhadap pecandu narkoba yang menjalani proses hukum, namun bukan sebagai pengedar narkoba. Jika sebagai pengedar narkoba maka, proses hukum akan dilakukan dengan ketat sesuai dengan peraturan perundangundangan. ${ }^{14}$

Pelaksanaan rehabilitasi untuk pecapendu narkoba yang tertangkap tangan pada tahap penyidikan, pertama-tama menentukan pecandu narkoba tersebut murni/konsumen atau pecandu merangkap pengedar. Tindakan selanjutnya adalah melakukan proses assessment oleh tim assessment terpadu.

Tim Assesment terpadu dibentuk berdasarkan kesepakatan. Pembentukan

14 Hasil wawancara dengan AKBP Agung Prabowo, Kepala Bidang Pemberantasan BNNP/Propinsi Jawa Tengah, kamis 9 juni 2016, pukul 09.10 WIB, di BNNP/Propinsi Jawa Tengah.
Peraturan Bersama. tim assessment terpadu di bawah lembaga BNN/Propinsi, $\mathrm{BNN} / \mathrm{Kab}, \mathrm{BNN} /$ Kota. Tim assessment dalam menjalankan tugasnya terbagi menjadi 2 tim, yaitu :

a) Tim hukum, yaitu pemeriksaan dari unsur Kepolisian, BNN, Kejaksaan dan Kemenkumham

b) Tim medis, yaitu pemeriksaan dari dokter dan psikolog.

Adapun tugas pokok dari tim assessment terpadu, tim hukum melakukan analisis pengembangan jaringan dalam kaitanya peredaran gelap narkoba dan berkoordinasi dengan pihak penyidik yang menanganani kasus tersebut. Tim medis melakukan pemeriksaan dari segi kesehatan dan kejiwaan pecandu, sehingga menjadi dasar rekomendasi langkah rencana terapi dan rehabilitasi.

Tim Assessment Terpadu juga mempunyai kewenangan yang mencakup, permintaan oleh penyidik untuk mendalami kasus dan analisis peran seorang yang ditangkap dan tertangkap oleh penyidik, guna menentukan sebagai pecandu narkoba atau pengedar narkoba. Apabila pecandu narkoba yang melaporkan diri di BNNP Jawa Tengah meminta untuk direhabilitasi, maka akan diarahkan untuk pemeriksaan oleh tim rehabilitasi yang berada di BNN selanjutnya akan dituntun untuk melakukan pemeriksaan medis di tempat yang telah mendapatkan rekomendasi baik mitra $\mathrm{BNN}$ maupun IPWL.

Bagan di bawah ini menunjukan alur seorang pecandu narkoba yang tertangkap tangan dan menjalani proses hukum yang ditempatkan di lembaga rehabilitasi sebelum dan sesudah putusan pengadilan. 


\section{Alur Penempatan Pecandu Narkoba di Lembaga Rehabilitasi Melalui Proses Hukum}

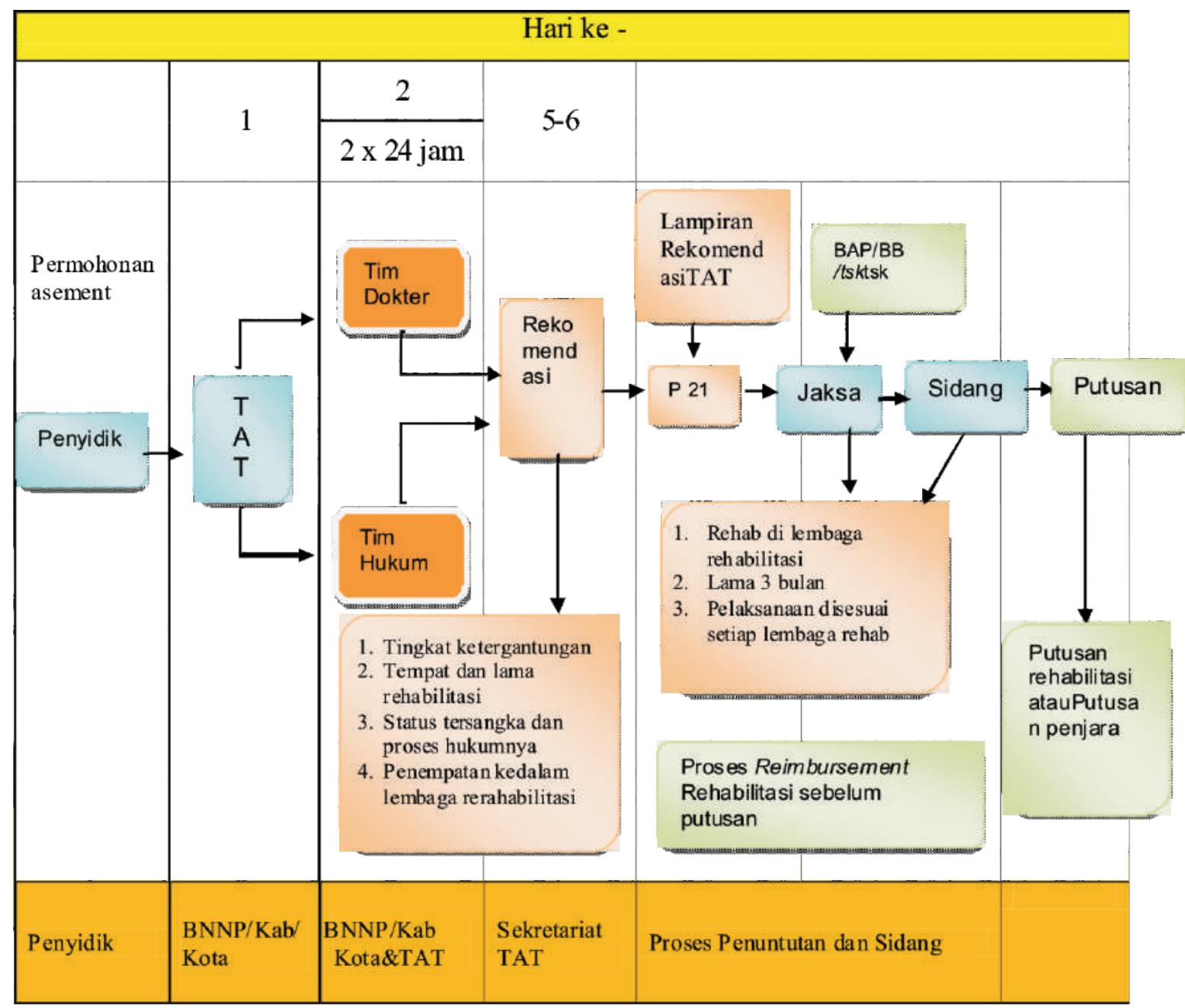

(sumber : Badan Narkoba Nasional Propinsi Jawa Tengah, 2016)

Pelaksanaan rehabilitasi bagi pecandu narkoba pada proses penegakan hukum diperoleh data seperti di bawah ini:

\section{a. Operasi Terpadu}

BNNP Jawa Tengah berkoordinasi dengan Satuan Unit Narkoba untuk menggelar operasi terpadu. Operasi dilakukan pada bulan Maret sampai bulan April 2016 di Polres Klaten, penangkapan dilakukan selama tiga kali, penangkapan pertama berhasil menangkap 7 pelaku saat hendak melakukan transaksi narkoba. Penangkapan kedua berhasil menangkap 2 pelaku, dan penangkapan ketiga berhasil menangkap 2 pelaku. Hasil dari operasi tersebut telah ditangkap 11 tersangka pecandu narkoba dengan lokasi penangkap an yang berbeda-beda, dengan barang bukti berupa narkoba dengan berat total 5,8 gram, dua diantaranya adalah pegawai negeri sipil yaitu AN (32) guru SD dan HR (46) anggota Satpol PP dan kesembilan lainya sebagian besar berprofesi wiraswasta. 


\section{b. Tindakan Penyidik dan BNNP Jawa Tengah.}

Proses penanganan oleh satuan Unit Narkoba dalam pemeriksaan dilakukan dalam 1x24 jam oleh penyidik, dari 11 (sebelas) tersangka, selama pemeriksaan indikasinya ada 9 (sembilan) pecandu narkoba dan 2 (dua) pengedar narkoba. 9 (Sembilan) pecandu narkoba oleh penyidik dilakukan permohonan assessment kepada BNNP Jawa Tengah. Hasil dari assessment 4 (empat) orang pencandu yang layak untuk mendapatkan rehabilitasi pecandu narkoba pada proses penegakkan hukum seperti tabel di bawah ini:

Penyalahguna narkoba pada proses penegakaan Hukum

\begin{tabular}{|l|l|l|c|}
\hline No & N a m a & \multicolumn{1}{|c|}{ Alamat } & Umur \\
\hline 1 & AN & Kebabonarum, Klaten & 32 tahun \\
\hline 2 & HR & Jogonalan, Klaten & 46 tahun \\
\hline 3 & SS & Klaten & 30 tahun \\
\hline 4 & SP & Klaten & 28 tahun \\
\hline
\end{tabular}

Sumber : BNN Propinsi Jateng di olah

Ke-4 (empat) tersangka dapat dititipkan sementara di lembaga rehabilitasi selama proses hukumnya berjalan. Berdasarkan BAP pemeriksaan Hasil Laboraturium dan BAP pemeriksaan penyidik BNNP Jawa Tengah yang dilengkapi dengan Surat Hasil Assessment Terpadu. Penetapan 4 (empat) pecandu untuk direhabilitasi berdasarkan barang bukti yang ditemukan dan dimiliki para pecandu yang tertangkap, dan hasil pengembangan kasus bahwa ke-empat pecandu tidak terlibat dalam peran jaringan peredaran narkoba. Hal ini merupakan sifat subjektif dan keyakinan dari penyidik BNNP Jateng. ${ }^{15}$

15 Hasil wawancara dengan Rusman Sugiarto, Anggota Penyidik BNNP/Propinsi Jawa Tengah, kamis 9 juni 2016, pukul 10.10 WIB, di BNNP/Propinsi Jawa Tengah.
Pelaksanann rehabilitasi BNNP Jawa Tengah melakukan koordinasi dengan RSUD Dr. Muwardi Solo yang ditunjuk sebagai IPWL untuk melakukan assessment medis terhadap ke-empat pengguna narkoba tersebut. Hasil pemeriksaan medis diketahui tiga diantaranya merupakan pecandu tahap menengah dan satu pecandu tahap awal dan belum mengalami tingkat ketergantungan komplikasi fisik dan psikiatrik. Sehingga ke-empat pengguna narkoba diberikan perawatan rehabilitasi medis dengan cara rawat jalan selama 3 bulan. ke-empat pelaku pecandu narkoba mengalami perkembangan yang baik. Meskipun menjalani rehabilitasi, proses pemberkasan perkara tetap dilanjutkan oleh penyidik. Ke-empat tersangka yang direhabilitasi dikenakan wajib lapor dua kali seminggu selama menjalani proses hukum oleh Satuan Unit Narkoba Polres Klaten yang telah berkoordinasi dengan BNNP Jawa Tengah. "Ketika perkara sudah dinyatakan lengkap (P 21), maka penyidik mengirim keempat pelaku beserta berkas perkara ke kejaksaan.

\section{a. Analisis}

Rehabilitasi tersangka pecandu narkoba yang dilakukan penyidik pada proses hukum, ini mendasari dari Peraturan Bersama, dan ketentuan Pasal 13 ayat (3) dalam Peraturan Pemerintah Nomor 25 tahun 2011, disebutkan bahwa pecandu yang sedang menjalani proses peradilan dapat ditempatkan kedalam lembaga rehabilitasi medis dan sosial.Tindakan penyidik Polri dan BNN tersebut merupakan bentuk koordinasi antar penyidik. Bentuk koordinasi yang dilakukan antar lembaga berdasarkan dengan ketentuan Pasal 84 Undang-undang Nomor 35 tahun 2009.

Menurut penjelasan anggota Deputi Rehabilitasi BNNP Jawa Tengah, di Jawa Tengah ada tiga pusat lembaga rehabilitasi yang dijadikan prioritas rekomendasi BNN untuk 
penempatan rehabilitasipecandu narkoba, walaupun masih ada alternatif lembaga rehablitasi lainya. Ketiga pusat lembaga rehabilitasi tersebut adalah, Rumah Sakit Umum Daerah (RSUD) Surakarta, Rumah Sakit Umum Daerah (RSUD) Dr. Moewardi, dan Rumah Sakit Jiwa Daerah (RSJD) Surakarta. ${ }^{16}$ Meskipun masih ada alternatif lembaga rehabilitasi yang lain.

Pelaksanaan rehabilitasi pada proses hukum dilakukan secara selektif, tidak semua pecandu narkoba direhabilitasi oleh BNNP Jateng, penyidik hanya akan memberikan rehabilitasi sebagai pecandu narkoba atau pengguna. Tindakan rehabilitasi selama proses hukum tidak diberikan kepada pecandu narkoba yang termasuk dalam kategori sebagai berikut :

a). Pecandu narkoba yang diketahui membawa barang bukti berupa narkoba dengan jumlah tertentu.

b). Pecandu narkoba yang merangkap sebagai pengedar narkoba.

BNNP Jawa Tengah hanya memberikan kesempatan rehabilitasi kepada tersangka pecandu narkoba yang tidak berperan dalam perearan narkoba dan tidak melebihi batas yang telah ditentukan.

Pelaksanaan rehabilitasi terhadap pecandu narkoba yang tertangkap tangan, akan direhabilitasi pada proses hukum berdasarkan kewenangan penyidik dengan mengajukan permohonan assessment dan selanjutnya direhabilitasi, "namun penyidik dalam memutuskan untuk mengajukan merehabilitasi tersangka sangat selektif, dan tidak semua pencadu narkoba akan diajukan permohonan untuk assessment", 17

Penempatan tersangkapecandu narkoba di lembaga rehabilitasi merupakan inisiatif dari penyidik. Tersangka juga dapat

\footnotetext{
16 Hasil wawancara dengan Sarah Kharisma Sari, Seksi Penguatan Lembaga Rehabilitasi BNNP/Propinsi Jawa Tengah, 27 Juni 2016, di BNNP/Propinsi Jawa Tengah.

17 Hasil wawancara dengan Purwanto, Anggota Penyidik BNNP/Propinsi Jawa Tengah, kamis 9 juni 2016, di BNNP/Propinsi Jawa Tengah.
}

melakukan permohonan untuk dilakukan rehabilitasi, namun hal ini merupakan kewenangan dari penyidik untuk menyetujui atau tidak. Berdasarkan fakta empiris dilapangan jika pecandu terlibat dalam peredaran, maka penyidik tidak akan memberikan rekomendasi rehabilitasi. Batasan tertentu jumlah barang bukti berupa narkoba pada saat tertangkap tangan, BNNP Jawa Tengah mengacu pada Surat Edaram Mahkamah Agung (SEMA) Nomor 4 tahun 2010 tentang Penempatan Penyalahgunaan, Korban Penyalahgunaan dan pecandu narkoba ke dalam Lembaga Rehabilitasi Medis dan Sosial. SEMA tersebut juga menjadi pertimbangan bagi hakim dalam menjatuhkan putusan rehabilitasi penyalahgunaan narkoba.

Di bawah ini di paparkan jumlah batasan kepemilikan barang bukti bagi tersangka untuk ditempatkan ke dalam lembaga rehabilitasi.

\section{Jumlah Batas Kepemilikan Barang Bukti Berupa Narkoba}

\begin{tabular}{|l|l|l|}
\hline No & Jenis narkoba & Jumlah \\
\hline 1 & $\begin{array}{l}\text { Kel. metamphetamine } \\
\text { (shabu-shabu) }\end{array}$ & gram \\
\hline 2 & Kel. MDMA (ekstasi) & 2,4 gr $=8$ butir \\
\hline 3 & Kel. Heroin & 1,8 gram \\
\hline 4 & Kel. Cocaine & 1,8 gram \\
\hline 5 & Kel. Ganja & 5 gram \\
\hline 6 & Daun Koka & 5 gram \\
\hline 7 & Meskalin & 5 gram \\
\hline 8 & Kel. Psilosylin & 3 gram \\
\hline 9 & $\begin{array}{l}\text { Kel. LSD } \\
\text { (d-lysergic acid } \\
\text { diethylamide) }\end{array}$ & 2 gram \\
\hline 10 & $\begin{array}{l}\text { Kel. PCP } \\
\text { phencyclidine) }\end{array}$ & 3 gram \\
\hline 11 & Kel. Fentamil & 1 gram \\
\hline 12 & Kel. Metadon & 0,5 gram \\
\hline 13 & Kel. Morfin & 1,8 gram \\
\hline 14 & Kel. Petidin & 0,96 gram \\
\hline 15 & Kel. Kodein & 72 gram \\
\hline 16 & Kel. Bufrenorfin & 32 mg \\
\hline
\end{tabular}

(sumber : SEMA Nomor 4 tahun 2010) 
Berdasarkan batas minimal kepemilikan barang bukti narkoba pada saat tertangkap tangan. Dapat diketahui bahwa apabila melebihi batasan maksimal, maka proses hukum tidak akan direhabilitasi. Hal ini didasarkan pada asas kehati-hatian dan didasarkan pada batasan jumlah kepemilikan barang bukti, serta diyakini jika pecandu yang tertangkap tangan ada kemungkinan terlibat jaringan pengedarnarkoba.

Penyidik dalam mendalami peran tersangka pencandu narkoba juga melakukan pengecekan terhadap sarana telekomunikasi dan informasi lainya yang dimiliki, hal tersebut untuk memastikan bahwa pecandu yang akan direhabilitasi bukan terlibat dan merangkap sebagai pengedar narkoba.

Pemeriksaan intensif terhadap pecandu yang tertangkap tangan, dilakukan sebagai upaya untuk mengantisipasi terhadap pecandu merangkap pengedar tetapi mengaku hanya sebagai pecandu saja. "Jika pada saat pemeriksaan diketahui pecandu narkoba yang tertangkap juga merangkap sebagai pengedar/bandar narkoba, maka pihak penyidik BNNP Jawa Tengah tidak akan memberikan kesempatan untuk direhabilitasi pada proses hukum yang dijalaninya. Hal ini dilakukan untuk mengantisipasi pelaku mengedarkan dan memperluas pemasaran narkoba di tempat rehabilitasi. Mengingat di tempat rehabilitasi dihuni oleh banyak pacandu, yang akan dengan mudah terpengaruh dan akan merusak jalannya masa rehabilitasi yang bertujuan untuk memulihkan pecandu". ${ }^{18}$ Penyidik tidak mau mengambil resiko untuk menempat kan pecandu yang juga pengedar narkoba di tempat rehabilitasi, dan mengantisipasi keamanan di tepat pusat lembaga rehabilitasi, karena ditakutkan akan

18 Hasil wawancara dengan AKBP Agung Prabowo, Kepala Bidang Pemberantasan BNNP/Propinsi Jawa Tengah, kamis 9 juni 2016, pukul 09.10 WIB, di BNNP/Propinsi Jawa Tengah. merusak program pelaksanaan rehabilitasi pecandu narkoba. Penyidik lebih memilih untuk tetap menahan dan memproses hukum tersangka pengedar narkoba yang sebagai pecandu narkoba tanpa me rehabilitasi.

Menentukan untuk merehabilitasi pecandu narkoba, diperlukan analisis dan pemeriksaan yang mendalam terhadap kasus penyalahgunaan narkoba. Berdasar kan bukti dilapangan, dan juga dipengarugi oleh keyakinan penyidik bahwa pecandu memang hanya konsumen bukan pengedar, sehingga apabila benar bahwa yang tertangkap hanyalah pecandu narkoba, "maka tindakan penyidik akan mengajukan surat permohonan kepada tim assessment supaya dilakukan pemeriksaan dan segera direhabilitasi berdasarkan rekomendasi dari tim assessment terpadu". ${ }^{19}$

Biaya pengobatan rehabilitasi pecandu narkoba, seluruhnya akan ditanggung oleh BNN (negara), berdasarkan rujukan dari pemerintah dan tersangka diketahui dari golongan yang kurang mampu. Namun, apabila tersangka diketahui dari golongan mampu dan terlebih tersangka memilih sendiri tempat untuk dilaksanakannya rehabilitasi, maka biaya sepenuhnya akan dibebankan kepada tersangka.

Berdasarkan data yang diperoleh menunjukan jumlah pecandu narkoba yang direhabilitasi dari hasil pemerikasaan tim assessment terpadu (TAT) pada wilayah Jawa Tengah, adalah sebagai berikut :

Jumlah pecandu narkoba

(Compulsary) yang Direhabilitasi

Selama Proses Hukum di Wilayah Jawa Tengah th 20115/12016

\begin{tabular}{|c|c|}
\hline Tahun & Jumlah \\
\hline 2015 & 58 Pecandu \\
\hline 2016 ( sd September) & 125 Pecandu \\
\hline
\end{tabular}

(sumber: BNNP Propinsi Jawa Tengah, 2016)

19 Hasil wawancara dengan Rusman Sugiarto, Anggota Penyidik BNNP/Propinsi Jawa Tengah, Kamis 9 Juni 2016, di BNNP/Propinsi Jawa Tengah. 
Penempatan pecandu yang direhabilitasi dilakukan di pusat lembaga rehabilitasi mitra BNN dan IPWL yang telah mendapatkan rekomendasi. Berdasarkan tabel jumlah pecandu yang direhabilitasi selama proses hukum telah terjadi peningkatan, pada tahun 2016 terjadi peningkatan lebih dari $50 \%$ dari tahun sebelumnya. Hal ini dikarenakan kerja keras dari lembaga BNN untuk memberantas peredaran gelap narkoba dan paradigma aparat penegak hukum untuk memberikan penanganan khusus pecandu dan pemakainarkoba untuk direhabilitasi.

Pecandu narkoba yang direhabilitsi pada proses hukum tidak akan dilakukan penahanan, namun akan ditempatkan di lembaga rehabilitasi sampai dengan selesainya program rehabilitasi atau penyidikan dinyatakan lengkap (P21) oleh pihak Kejaksaan. Meskipun pecandu narkoba tidak dilakukan penahanan oleh penyidik pemberkasan kasus tersebut tetap dilanjutkan penyidikan sampai ke persidangan. "Secara hukum, pecandu tidak ditahan, tetap menjalani persidangan di Pengadilan, hakim wajib memberikan putusan rehabilitasi sesuai dengan ketentuan Pasal 103 Undang-undang narkoba". ${ }^{20}$ Keamanan selama pelaksanaan di lembaga rehabilitasi, BNNP Jawa Tengah tanggungjawab seluruhnya diseerahkan kepada pihak lembaga rehabilitasi, pengawasan dari lembaga rehabilitasi dapat berkoordinasi dengan Kepolisian setempat. Kepolisian dilibatkan dalam pengawasan selama pelaksanaan rehabilitasi dilakukan guna memastikan jalanya pelaksanaan rehabilitasi tersangka berjalan aman.

Pecandu narkoba yang ditempatkan direhabilitasi pada proses hukum, berdasarkan pada putusan hakim di pengadilan, apakah pecandu akan dijatuhi hukuman penjara atau dijatuhi hukuman rehabilitasi. Untuk

\footnotetext{
20 Hasil wawancara dengan AKBP Agung Prabowo, Kepala Bidang Pemberantasan BNNP/Propinsi Jawa Tengah, kamis 9 Juni 2016, di BNNP/Propinsi Jawa Tengah.
}

membantu hakim dalam menjatuhkan hukuman maka dilampirkan "Rekomendasi selama assessment juga diserahkan kepada hakim melalui penyidik dan penuntut umum agar menjadi dasar pertimbangan hakim dalam menjatuhkan putusan". ${ }^{21}$ Berdasarkan Pasal 103 Undang-undang Nomor 35 tahun 2009, hakim dapat memutuskan pecandu narkoba agar ditempatkan di lembaga rehabilitasi. Namun selama pelaksanaan rehabilitasi pada proses hukum akan dihitung sebagai masa menjalani hukuman.

Menurut Kepala Bidang Pemberantasan BNNP Jawa Tengah, apabila pada saat proses hukum pecandu narkoba tidak dilakukan rehabilitasi dan hanya dilakukan penahanan, oleh karena itu pecandu dapat mengajukan gugatan praperadilan, sesuai dengan KUHAP. Berdasarkan Pasal 127 bahwa ancaman hukuman bagi penyalahguna narkoba tidak melebihi 5 tahun Pecandu tidak boleh dilakukan penahanan melainkan sesuai dengan kebijakan peraturan yaitu ditempatkan di lembaga rehabilitasi dan mempertimbangakan barang bukti dari ketentuan SEMA Nomor 4 tahun 2010 dan diketehui hanya sebagai penyalahguna narkoba. Hal ini yang menjadikan penanganan tindak pidana pecandu narkoba berbeda dengan kejahatan-kejahatan lainnya. ${ }^{22}$ Khusus pecandu yang merangkap sebagai pengedar dan pecandu yang membawa barang bukti melebihi batas tetap akan direhabilitasi, namun dalam pelaksanaanya berbeda. Perbedaannya yaitu pecandu konsumen akan ditempatkan di lembaga rehabilitasi milik swasta maupun negeri yang telah ditunjuk BNN dan Pemerintah. Sedangkan pecandu yang merangkap sebagai pengedar dan melebihi jumlah akan direhabilitasi di Rumah Tahahan dan Lembaga Pemasyarakatan bersamaan saat menjalani hukuman. 


\section{Kesimpulan}

Berdasarkan hasil penelitian dan pembahasan dapat disimpulkan sebagai berikut:

1. Focus Pelaksaan rehabilitasi bagi pecandu narkoba secara sukarela adalah Rawat jalan. Metode Rehabilitasi dengan menjalani: (1) Rebabilitasi Medis yang terdiri dari (2) Rehabilitasi Sosial dan (3) Pasca Rehabilitasi. Pasca rehabilitasi dirinci menjadi tiga tahap yaitu: (1) tahap orientasi Program, (2) Tahan Pelatihan dan (3) Tahap kembali ke Keluarga.

2. Pelaksanaan rehabilitasi pecandu narkoba yang tertangkap tangan dan menjalani proses hukum, dapat ditempatkan kedalam lembaga rehabilitasi medis dan sosial yang telah direkomendasikan. Tindakan penyidik yang menangani pecandu sebelumnya akan melakukan proses assessment oleh tim hukum dan tim medis yang berada di BNN dan rumah sakit, namun dalam pelaksanaanya dilapangan tidak semua pecandu yang tertangkap akan direkomendasikan untuk direhabilitasi, hal ini berlaku bagi pecandu yang merangkap sebagai pengedar dan melebihi jumlah barang bukti tertentu sesuai dengan SEMA Nomor 4 tahun 2014. Walaupun selama proses penegakan hukum direhabilitasi pemberkasan perkara tetap dilanjutkan sampai ke pengadilan.

\section{DAFTAR PUSTAKA}

Atmasasmita, Romli, 1997, Tindak Pidana Narkotika Transnasional Dalam Sistem Hukum Pidana Indonesia, Bandung: PT. Citra Aditya Bakti.

Hadiman, 1996, Perlakukanlah Barang Haram Ecstasy, Narkotika Dll Seperti barang Haram Lainnya, Jakarta: Yayasan Al Washilah.
Hamzah, Andi, dan Surachman, 1994, Kejahatan Narkotika Dan Psikotropika, Jakarta: Sinar Grafika.

Hamzah, Andi, 1985, Pengantar Hukum Acara Pidana Indonesia, Jakarta : Ghalia Indonesia.

Huda, Chairul, 2006, Dari Tiada Pidana Tanpa Kesalahan Menuju Kepada Tiada Pertanggungjawaban Pidana Tanpa Kesalahan, Jakarta: Prenada Media.

Lisa, Juliana, dan Nengah Sutrisna, 2013, Narkoba, Psikotropika Dan Gangguan Jiwa, Yogyakarta: Nuha Medika.

Ma'roef, Ridho, 1986, Narkotika Bahaya Dan Penanggulanganya, Jakarta : Karisma Indonesia.

Makaro, Taufik, Suhasril, dan Moh. Zakky, 2005, Tindak Pidana Narkotika, Jakarta: Ghalia Indonesia.

Rena, Yulian, 2009, Victimologi, Yogyakarta: Graha Ilmu.

Supramono, Gatot, 2009, Hukum Narkoba Indonesia, Jakarta: Djambatan. 2000, Hukum Acara Pengadilan Anak, Jakarta: Djambatan.

Soedjono, 1973, Narkotika Dan Remaja, Bandung: Alumni.

Soerjowinoto, Petrus, dkk, 2014, Metode Penulisan Karya Hukum, Semarang: Fakultas Hukum Unika Sogijapranata.

Soemitro, Ronny Hanitijo, 1995, Metodologi Penelitian Hukum, Jakarta: Ghalia Indonesia.

Marzuki, Peter Mahfud, 2006, Penulisan Hukum, Jakarta: Kencana Media Group.

Sudarto, 1981, Hukum dan Hukum Pidana, Bandung: Alumni.

Waluyo, Bambang, 1991, Penelitian Hukum Dalam Praktek, Jakarta: Sinar Grafika. 
Moeljatno, 2009, Kitab Undang-undang Hukum Pidana, Jakarta: Bumi Aksara.

I, Undang-Undang Nomor 8 tahun 1981 tentang Hukum Acara Pidana.

RI, Undang-Undang Nomor 35 tahun 2009 tentang Narkotika.

RI, Undang-Undang Nomor 5 tahun 1997 tentang Psikotropika.

RI, Undang-Undang Nomor 25 tahun 2011 tentang Pelaksanaan Wajib Lapor Pecandu Narkotika.

RI, Undang-Undang Nomor 23 tahun 2010 tentang $B N N$.

RI, Peraturan Pemerintah Nomor 25 Tahun 2011 tentang Pelaksanaan Wajib Lapor bagi Pecandu Narkotika.

RI, Peraturan Kepala BNN Nomor 11 tahun 2014 , tentang Tata Cara Penanganan Tersangka dan/atau Terdakwa Pecandu Narkotika dan Korban Penyalahgunaan Narkotika ke dalam Lembaga Rehabilitasi.

RI, Surat Edaran Mahkamah Agung Nomor 04 tahun 2010, tentang Penempatan Penyalahgunaan, Korban Penyalahgunaan dan Pecandu Narkotika Ke dalam Lembaga Rehabilitasi Medis dan Lembaga Rehabilitasi Sosial.
RI, Peraturan Bersama Ketua Mahkamah Agung, Menteri Hukum dan Hak Asasi Manusia, Menteri Kesehatan, Menteri sosial, Jaksa Agung, Kepala Kepolisian, Kepala BNN, Nomor: 01/PB/MA/III/2014, Nomor: 03 tahun 2014, Nomor: 11 tahun 2014, Nomor: 03 tahun 2014, Nomor: PER-005/A/JA/03/2014, Nomor: 01 tahun 2014, Nomor: PERBER/01/ III/2014/BNN, tentang Penanganan Pecandu dan Korban Penyalahgunaan Narkotika Ke dalam Lembaga Rehabilitasi.

RI, Peraturan Menteri Kesehatan, Nomor 13 tahun 2014, tentang Perubahan Penggolongan Narkotika.

Internet, diakses pada tanggal 18 Februari 2016, www:http://m.kompasiana. $\mathrm{com} / \mathrm{phad}$ li/jumlah-penggunanarkotika-di-indonesia_553 ded8d6ea834b92bf.

Internet, diakses pada tanggal13 Juli 2016, WWW;//KBBI.web.id/hambatan. 